\title{
A UNIDADE FEBRIL DE INVENÇÃO DE ORFEU, DE JORGE DE LIMA
}

\author{
Suene Honorato
}

"Pra unidade deste poema, / ele vai durante a febre" (LIMA, 1992, p. 526). Nesses versos do poema XXIII do Canto I de Invenção de Orfeu, pode-se ler um programa de escrita em dois passos: 1) afirma-se a busca de uma unidade; 2) a unidade se constrói na doença. Portanto, não uma unidade afeita à lógica racional, empreendida por um sujeito "são", mas conduzida pelo delírio de um organismo - o próprio poema - febril. O poema, em seu todo, se dá a ver como organismo adoecido. Quais seriam as motivações desse adoecimento? Por que o poema postula um tal tipo de unidade, ao invés de simplesmente abdicar-se dessa busca?

Publicada em 1952, Invenção de Orfeu, de Jorge de Lima, se propõe como epopeia moderna, em que o lirismo de suas formas daria o tom de desajuste em relação aos moldes da epopeia tradicional. Os subtítulos anunciam: "Biografia épica, / Biografia total e não / uma simples descrição de viagem / ou de aventuras. / Biografia com sondagens; / Relativo, absoluto e uno / mesmo o maior canto é / denominado - Biografia" (LIMA, 1992, p. 505). A ideia de compor uma biografia (de quem? de quê?) supõe narratividade, composição de relações causais entre fatos narrados, apreensão de uma totalidade - termos que reforçam o aspecto épico do poema. Dividida em dez cantos, à maneira de Os lusíadas, a obra é composta por poemas de métrica variada; a abundância de sonetos, especialmente de versos decassílabos, que podem ser lidos como peças separadas, indica a predominância do tom lírico, somada à linguagem metaforizante de traço surrealista. 
A conjugação entre épico e lírico em Invenção de Orfeu chamou a atenção da crítica desde sua publicação e tem sido considerada como motivação para o alegado hermetismo do poema, ${ }^{1}$ tensionando a distância a que o épico e o lírico, tomados abstratamente, se colocam (STAIGER, 1969); daí sua unidade febril, fragmentada, caótica, embriagada. Para Anazildo Vasconcelos e Cristina Ramalho (2007, p. 50), por exemplo, o gênero épico teria sofrido um processo de "evolução natural" caracterizado pela "passagem da predominância narrativa para a predominância lírica". No caso de Invenção de Orfeu, a ideia da prevalência do aspecto lírico, ainda que verificável, contribuiu para a fixação da imagem de poema hermético, inacessível ao leitor, que a torna um objeto autônomo porém dispensável, o belo inútil e "fruível" para poucos eleitos. Creio que outras possibilidades de leitura, igualmente verificáveis, permitem recuperar o problema da incidência da poesia no mundo posto pela própria obra e, com isso, o vínculo com as experiências do leitor. Dessa perspectiva, torna-se possível investigar os motivos do "adoecimento" do poema e da busca por unidade.

Ao invés de considerar a obra um objeto autônomo, que não estabelece ligações com o universo extraliterário e vira as costas ao leitor, proponho discutir sua tentativa de incidir sobre esse universo. Nesse movimento, que expressa um desejo transitivo, o poeta - personagem da aventura de "fundação da ilha", como anuncia o título do Canto I - encena uma contradição: ora afirma, ora nega que a poesia seja capaz de cumprir a tarefa proposta. Essa contradição estrutura a obra do primeiro ao último Canto. Ao final, será feita com o leitor a aliança de recomeçar o poema; nesse poema por fazer é que efetivamente a palavra poética realizaria seu poder fundante. É como se todo o poema feito fosse uma tentativa de "cura" da linguagem, anunciada como possibilidade para depois que o poema termine.

A busca por fundar um mundo pela palavra poética, em Invenção de Orfeu, sinaliza a insuficiência do mundo em que o poeta se inscreve. $\mathrm{O}$ presente da enunciação geralmente marca um tempo sombrio, de privação e sofrimento. As referências míticas e históricas dão testemunho deguerras de conquista, motivadas pela ganância e soberba humanas - índice da degeneração do homem desde o drama da Queda. O poema se apresenta como organismo adoecido na correlação com um mundo degenerado. Se fosse possível abstrair tal correlação, a fundação da ilha poderia se efetivar

1 A título de exemplo, cf. Canabrava (1997); Telles (1979); Merquior (1996); Andrade (1997). Remate de Males, Campinas-SP, v. 37, n. 1, pp. 217-239, jan./jun. 2017 
como uma espécie de Pasárgada bandeiriana. A questão, para o poeta de Invenção de Orfeu, é justamente a incerteza, a ausência de garantias de que a palavra poética consiga incidir sobre o mundo degenerado que a adoece.

Nas mãos de Orfeu, a lira, um simples instrumento de cordas, tornouse mágica, capaz de promover inexplicáveis transformações nos seres (animados e inanimados) que a escutavam: "As árvores inclinam-se para ouvir o divino músico, os rochedos mudam de lugar para melhor escutálo, os rios suspendem o seu curso, as feras, subitamente amansadas, rastejam-lhe aos pés" (MÉNARD, 1991, p. 56). A influência de Apolo sobre a música de Orfeu, de quem o cantor trácio seria filho, talvez explique seu caráter civilizatório: o encantamento de que os seres eram tomados ao ouvi-lo tocar arrefece impulsos destrutivos e, por isso mesmo, impõe uma pausa para a execução de sua arte. Quando Orfeu toca, nada mais importa a não ser sua música; tudo o mais cala.

O ofício de Orfeu torna-se tanto mais necessário quanto mais o mundo à sua volta conserva impulsos destrutivos. A existência de Orfeu sinaliza um universo caótico sobre o qual a incidência de sua música torna-a essencial, porque nele insere um momento de suspensão que conserva a harmonia entre os seres. Por isso, essa face do mito é imprescindível para a construção a que o poeta se pretende em Invenção de Orfeu, justificando a dedicação a uma tarefa comprometida com o reencantamento do mundo. O poeta procura aprender com Orfeu a inventar uma organização do caos mundano que, embora precária, porque dura apenas o instante da execução da música, possa incidir na realidade traçada dentro do poema, amenizando as tensões que se acumularam na história mítica e factual a que ele se refere, e afastando o caráter sombrio que o presente da enunciação denuncia.

No Canto VII, "Audição de Orfeu", encontra-se um longo poema (III) composto de estrofes de onze versos decassílabos brancos, em que o poeta fala a respeito do seu ofício. Começa por notar um estado de coisas que se caracteriza pela ausência de luz e pelo silêncio, assinalando a existência do caos. De dentro desse mundo caótico, pensa escutar um chamado. A incerteza sobre se existe e de onde parte o chamado traz certa tensão para o poema, fazendo que o poeta se reconheça incapaz de exercer a função a 
ele designada. As imagens de silêncio marcam o poema, motivadas tanto por condições exteriores, como característica de um universo refratário à poesia (um mundo adoecido), quanto pela interioridade do poeta diante da tensão instituída no poema. O poeta convoca "secretos numes, causas, entidades, / mãos vigilantes [...]” (LIMA, 1997, p. 678) para devolver-lhe a capacidade de expressão. Surge Orfeu e promove o nascimento do poema: “o poema nasce: / Orfeu, Orfeu, Orfeu que me desperta” (p. 678). O deus assim aparece:

Está ele de alvíssaras nos olhos, apenas reclinado, apenas arcoíris desmortalhado, mas ode, e arde. E aí estão, estes túneis tão compactos que cruzam o silêncio das palavras. Que relativas sombras o aspergiram? Que arcanos sucessivos o inspiraram? Que flamantes luzeiros imprevistos! (LIMA, 1997, p. 678).

As alvíssaras que possui nos olhos anunciam as boas-novas. Orfeu parece ressuscitar, na imagem do arco-íris sem mortalha, sugerindo a recuperação de sua luminosidade. A suposição da morte de Orfeu não tem no poema causa referida. Recobrando forças, Orfeu "ode e arde": o verbo arder, conjugado no presente do indicativo, sugere o neologismo "ode", conjugação do verbo "odar", fazer odes, formado a partir do substantivo correspondente; a ardência sugere calor e brilho. O aparecimento de Orfeu modifica a situação de um mundo adoecido descrita no início do poema: o poema nasce porque Orfeu traz as palavras que cruzam o silêncio e irradia luz intensa, como "flamantes luzeiros imprevistos". Porém, o poeta volta o olhar ao mundo e constata novamente o silêncio das coisas; mais uma vez, deseja ser tomado pelas palavras, implorando às coisas que as pronunciem: "Falai-me imunes coisas, coisas vivas, / livrai-me desse triste solilóquio” (LIMA, 1997, p. 679). A situação em que o poeta se encontra é oposta à de Orfeu: enquanto o deus, ao dedilhar sua lira, envolve os seres com sua música, o poeta está incomunicável. Nesse momento, o Orfeu convocado na obra mantém seu aspecto mítico, irreal, e se coloca à distância do poeta, como um símbolo a ser alcançado, constantemente ameaçado pelo silêncio que o circunda.

Na sequência, o poeta dirige-se a Orfeu sob o epíteto de "mão olímpica", referindo-se à sua habilidade musical: 


\begin{abstract}
Compreendo, mão olímpica, teus signos, teu apontar abaixo, aguda seta, de sentenças à carne impermanente, teus ciúmes dos seres naufragados, teu ensino, teu certo movimento. Persiste, mão olímpica, nos lábios queimados por teus astros foragidos. Eu tíbio, eu tão sonâmbulo, eu recém, eu esconso, eu incerto, opto por ti, Sutil Pessoa Eterna. Sou tremor, cabeça, pés. Também meu pelo sórdido (LIMA, 1997, p. 679).
\end{abstract}

No trecho, apresentam-se novos elementos a respeito de Orfeu, que estão além da imagem de músico. $\mathrm{O}$ poeta dirige-se a ele como símbolo religioso, segundo um vocabulário tomado de empréstimo do cristianismo: além de designá-lo como "Pessoa Eterna", o poeta se inferioriza diante dele, oferecendo-lhe seu temor, como se estivesse aos pés do Cristo ressuscitado. Mas também se apresenta como um iniciado, que "compreende" seus ritos, dentre os quais assinala a condenação "à carne impermanente". Tais elementos evocam o orfismo, espécie de doutrina religiosa que teria tido grande popularidade até os primeiros séculos da era cristã. $O$ tom religioso com que o poeta se dirige a Orfeu devoto ("Sou tremor") e confessando sua humanidade ("Eu tíbio, eu tão sonâmbulo, eu recém, / eu esconso, eu incerto [...]"; "meu pelo sórdido") - direciona-se à busca da salvação, uma dimensão ausente do mundo homérico e que o orfismo insere no pensamento grego, já que, no universo olímpico, a noção de destino pré-determinado pelas Moiras impedia que o indivíduo concebesse suas atitudes em prol da salvação. Além disso, a imagem de Orfeu "desmortalhado" no início do poema se sobrepõe à do Cristo ressuscitado, o que não é estranho se se considerar a história das religiões. Ressalte-se a influência de Platão no cristianismo, influenciado, por sua vez, pelo orfismo. Há semelhanças notáveis entre ambos: a crença em um além-mundo, a possibilidade de salvação, a dualidade entre corpo e alma, a dupla natureza humana, dentre outras.

Em busca da salvação, o poeta nota que sua postura parece ser contrária à dos demais seres e lamenta que eles não respondam ao canto de Orfeu, embora este se faça presente: "tudo lhe escuta as odes invocadas / mas cala seus murmúrios e seus ritos” (LIMA, 1997, p. 680). O poeta, ao contrário, se anuncia como o ser designado para a poesia, que participa do/experimenta o universo da divindade: "Pois desde o céu em que essa 
luz foi minha / com beijo largo e flechas de martírio / sedes divinas vieram me beber / a mim a diagonal de luz esquálida” (p. 680). Nesses versos, a missão poética é vista como atitude sacrificial; o poeta se apresenta ao mesmo tempo como um eleito, a quem a vinculação com o sagrado é imposta, e como um pária. A imagem da "diagonal de luz esquálida" parece conferir certa fragilidade ao poeta no desempenho da missão a que é designado. A diferença que estabelece com os demais seres causa-lhe sofrimento; o poeta, tal como Orfeu e Cristo, é mártir cujo padecer atesta sua designação. É também o profeta que procura saber "como delinear a rota augúria" (p. 680). ${ }^{2}$

Depois de perder Eurídice, Orfeu fora sacrificado pelas mênades desprezadas; Cristo também o foi, por uma multidão que não acreditava que ele fosse o filho de Deus enviado para remir os pecados da humanidade. O poeta, também ele ignorado pelos demais seres, envolvido em silêncio e renunciando a si em favor de sua tarefa, refere um sacrifício: “[...] Tambores vingativos / vieram com pulsos loucos e mataram / nas ternuras das tardes as infâncias" (LIMA, 1997, p. 681). A presença dos tambores confere ao sacrifício a imagem de um ritual público; o que se assassina são infâncias, vítimas inocentes. Trata-se de um sacrifício que, na sequência, é identificado ao Holocausto praticado pelos nazistas: "julgam-se os únicos, / raça preclara, sangue de demiurgos / [...] e tudo contra Aquele. Eis os tambores!" (p. 681). Ao lado desses versos, a anotação de Jorge de Lima: "Tambores fascistas contra Aquele".

Os crimes cometidos pela humanidade levam o poeta a constatar que a maldade é atributo humano desde o início dos tempos, definido já dentro do mito de criação do mundo. Como ocorre em outros momentos, nesse poema soma-se a alusão ao Gênesis, com a presença do mal: "Esse arcanjo banido, desfolhando-se? / Aquiescência. No início havia a mancha. / Inconsumptível mancha, nuvem nossa. / E o céu pesado sobre. Éramos um!" (LIMA, 1997, p. 683, grifo nosso). A glosa do versículo de abertura do Evangelho de João $(1,1)$ - "No princípio era o verbo" - aponta a presença consentida do mal; a unidade estabelecida não se dá entre deus e os homens, mas entre estes e o demônio. A sobreposição de "mancha" e "verbo" sugerem a falência da linguagem como princípio unitário do poema.

2 Áugure era o sacerdote que, entre os antigos romanos, revelava os desígnios divinos pela leitura do voo das aves. 
Na sequência, o poeta relembra o paraíso edênico, com imagens de tranquilidade, evocando a vivência harmoniosa e a nomeação dos seres. A lembrança do paraíso edênico torna o poeta nostálgico daquilo que não viveu e deseja experimentar: "Convoco essas paisagens esvaídas: / sou névoa, elas são névoa, somos um / só estrangeiro nesse vácuo imenso" (LIMA, 1997, p. 683). Ao invés de proclamar-se um ser à parte, que padece as consequências da designação, aqui o poeta se reconhece nos demais seres, pela condição de exilados. A lembrança das paisagens convocadas, por serem apenas névoa, opõe-se ao imenso vácuo; de névoa também se constituem os seres nos quais o poeta se reconhece. A fantasmagoria das lembranças e dos seres, bem como do próprio poeta, confere força à imagem do vazio que tudo consome. Nos versos seguintes, o poeta se metamorfoseia em mundo: atlas, polos e mares se transformam no corpo do poeta identificado a todos os seres. A metamorfose é uma via de mão dupla: de um lado, parece ser consequente da poderosa assimilação de todas as coisas pelo vazio; de outro, éa própria força de assimilação de todas as coisas que o poeta toma para si a fim de promover a fundação de mundo pela palavra poética. O poema parece assumir essa segunda direção, se encaminhando para a fundação de uma nova imagem do mundo: "Novas terras e sóis, novas esferas / nascem de extremo a extremo. Ó que gemidos / na glória das manhãs reconquistadas!" (p. 685). O surgimento do mundo saudado nesses versos permitirá ao poeta retomar a afirmação do poder fundante da palavra. Se Orfeu com seu canto despertava os seres para um estado de felicidade e calma, o poeta promete despertar o próprio canto:

\footnotetext{
Desperta quieto brilho, nota arisca, eu farei voar as flechas que te crivam como prismas gritantes, como tigres, como forças ferozes, como infernos, como espadas de guerra, como gritos. Aguarda, ó dia do alto, teu reflexo contido nas trombetas terminais. Mastins celestes, cisnes, vias-lácteas, exatas nebulosas, signos, Hércules, e novas invenções, coisas de coisas, apraz-me pronunciar-vos, sou vosso áugure (LIMA, 1997, pp. 685-686).
}

A poesia - luz ("quieto brilho") e música ("nota arisca”) - deve ser despertada em face do mundo que a refrata/adormece. O poeta deve fundar um microcosmo onde ela esteja livre daquilo que a faz sucumbir, das flechas que a ferem, metaforizadas com signos que indicam sofrimento Remate de Males, Campinas-SP, v. 37, n. 1, pp. 217-239, jan./jun. 2017 
e força destrutiva (gritos, feras, espadas). A confluência de imagens luminosas e celestes (dia do alto, vias-lácteas, nebulosas), associadas ao despertar do canto, anuncia, pelas "trombetas terminais", o dia do Juízo Final; assim, o poeta se apresenta como anunciador da salvação.

No desenvolvimento do poema, observa-se que o mundo ao qual o poeta alude é não só o mundo pós-edênico bíblico, como, historicamente, a civilização ocidental, cujo saldo de desenvolvimento, ilustrado pela referência ao Holocausto, soa negativo. A possibilidade de expiação é vislumbrada na reinvenção do mundo por meio da palavra poética, sendo o poeta-áugure o anunciador das boas-novas. Mas a efetividade dessa expiação é precária e situa-se no desejo projetado num futuro incerto. Alguns versos depois, o desejo se expressa nos verbos colocados no imperativo: "Dorme infante, cintila estrela, pranto / desce dos olhos simples, lâmpada alta / cobre os amantes. Som de mar, sossega / as tristezas das ruas. Amanhãs" (LIMA, 1997, p. 686, grifo nosso). O poeta deseja a vigência de um tempo de harmonia em que, sob a luz das estrelas e o som do mar, a calma reja a vida cotidiana. A subversão sintática na flexão do advérbio "amanhã" parece distanciar ainda mais a concretização do desejo, pela multiplicação do tempo colocado no plural.

Sendo precária, a possibilidade de salvação deve constituir uma busca permanente, como se percebe no poema XXVII do Canto III, "Poemas relativos”, em que o poeta direciona um questionamento a Orfeu:

Contemplar o jardim além do odor

e a mulher silenciosa entre semblantes,

e refazê-los todos, todos antes

que o tempo condenado os atraiçoe.

Porque eu quero, em memória refazê-los:

flor longínqua, mulher não pertencida, substância inexistente, móvel vida,

intercessão de nadas e cabelos.

E meus olhos ausentes me espiando entre as coisas caducas e fugaces a minha intercessão em outras faces.

Orfeu, para conhecer teu espetáculo, em que queres senhor, que eu me transforme, ou me forme de novo, em que outro oráculo?

(LIMA, 1997, pp. 609-610). 
Mais uma vez, a fantasmagoria dos objetos refrata a voz do poeta e impõe a busca pela fixação das coisas através da palavra. A operação anunciada nos dois quartetos é a de contemplar e refazer as imagens, antes que sejam consumidas pelo tempo. O poeta deseja fixar o "jardim além do odor", sugerindo a tentativa de conferir ao objeto uma concretude que o cheiro não lhe atribui, e a "mulher silenciosa entre semblantes", imagem que destaca sua face, a que o silêncio confere certo ar de mistério, em detrimento da imprecisão das demais faces entre as quais é situada. Na sequência, a recomposição da memória pela palavra poética enuncia as imagens não pela concretude, mas pela ausência de substância: flor que se perde na distância, mulher que não se possuiu, vida que não se fixa, intercessão sem objetivo. A vontade de fixar objetos pela palavra poética se realiza pela negatividade, isto é, pela inscrição de sua ausência.

Nosdoistercetos, a negatividadecomqueosobjetossãopresentificados no poema se direciona à própria imagem do poeta: seus olhos, sob a marca da ausência, são postos entre as coisas que o espiam; como elas, serão apagados pelo tempo. A intercessão dirigida a Orfeu parece indicar o caminho para a afirmação do poder fundante da palavra poética, que os versos anteriores atestam fracassar. Para recuperar o poder de Orfeu, o poeta propõe se formar em novo oráculo ou se transformar naquilo que o deus lhe exigir. O Canto III, "Poemas relativos", trabalha especialmente o motivo das coisas que não têm natureza fixa e se transformam em outras; daí os poemas, e todas as coisas, serem relativos. A metamorfose é um elemento importante para a construção da nova cosmogonia pelo poeta, afinal "como conhecer as coisas senão sendo-as?" (LIMA, 1997, p. 694). No caso do poema citado, ela se liga ao desejo de conhecer o espetáculo de Orfeu. Em outra passagem, o poeta diz querer assumir "a feição do deus órfico" (p. 689): o poeta deseja se fazer um iniciado nos mistérios órficos a fim de reproduzir, nos limites da obra, sua invenção cosmogônica e poético-musical, isto é, conceber a criação poética como resgate do poder fundante da palavra. Nesse sentido, tanto o poema III do Canto VII quanto o poema XXVII do Canto III evocam o Orfeu que tem o poder de suspender, ao menos por um instante, a percepção do adoecimento do mundo e que contribui para a afirmação do poder fundante da palavra poética, ainda que esse poder não se declare efetivo no plano do poema. 
Se a habilidade musical de Orfeu promove a harmonia entre os seres e a suspensão do caos mundano, também é responsável por conduzi-lo à própria anulação. O Orfeu que descumpre a condição imposta pelos deuses conhece a inevitabilidade do fracasso: não logrará retirar Eurídice das trevas e, com isso, silenciará e será assassinado pelas mênades. Em Invenção de Orfeu, esse segundo aspecto revela complementaridade ao primeiro: Orfeu não é apenas o deus que encanta os seres com sua lira, mas também aquele que falha em seu projeto de resgatar Eurídice do mundo dos mortos, Orfeu impotente que se entrega ao fracasso, como evidencia o poema XI do Canto II.

1 A mão de Orfeu, enorme destra abateu-se no peito, funda ausência, tão suave inexistente mão; foi delação das coisas,

5 inibida mão, ecos martelando-a, ecos que são cruéis e inexoráveis como as sublevações que retornaram e retornaram quando o deus construía; e agora há éguas nulas nos silêncios,

10 as éguas da fecundação final planturosas e cheias de pistilos viscosos como suas lesmas, vermelhos como seus relinchos que martelam a mão êxul de Orfeu, os retinidos ecos

15 temperados de cor, eram dele, de Orfeu deus sonoro e terrível, hoje vago, vago tão vago como sua vaga destra; nem mais diuturna nem com os androceus dos dedos musicais, amanhã cinco

20 apenas dedos reais humanos, cinco apenas, cinco sinos sem seu íris;

funda submersão desse deus, agora com seu deão de cerimônias inventando-lhe os gestos,

25 conduzindo-lhe a mão ao seio dos infernos, contando-lhe até cinco apenas dedos fiéis à delação desse deão que aponta a aparência de Orfeu (LIMA, 1997, pp. 570-571).

No Canto II, "Subsolo e supersolo", o poeta se filia a uma raça degenerada que, mítica e historicamente, padece os crimes cometidos. De um lado, a aflição decorrente do reconhecimento de pertença a essa raça; de outro, a necessidade de buscar alternativas para o estabelecimento 
da paz. Nesse contexto, o poema XI exibe Orfeu destituído de seu poder encantatório, assinalando a falência do canto que estabelece a comunhão entre os seres.

O poema é, curiosamente, o único de Invenção de Orfeu cuja métrica não é regular, com versos que variam de seis a doze sílabas poéticas. A estrutura frasal não é linear: compõe-se de apenas um período, em que as ideias se relacionam por associação e o ponto-e-vírgula demarca orações que se vão encaixando sem os componentes frasais necessários à ordenação lógica do discurso, característica que se acentua ao longo do poema. Os três primeiros versos, por exemplo, ainda compõem uma oração ordenada ao gosto do discurso racional, em comparação aos sete versos finais, em que orações subordinadas adjetivas (três reduzidas e uma desenvolvida) se encaixam umas nas outras, sem a presença da oração principal, numa enumeração associativa de ideias.

Poder-se-ia verificar no poema, em outros termos, aquilo que Leo Spitzer (1968) chamou de "enumeração caótica", como característica marcante da poesia moderna, referida a autores como Whitman, Claudel, Ruben Darío, Neruda, dentre outros: enumeração de coisas díspares, oriundas de campos semânticos que parecem se repelir, mas que assimilam formalmente a fragmentação do mundo moderno. Em tese, o verso livre se presta mais prontamente à assimilação desse recurso; o próprio Jorge de Lima, em obras produzidas a partir do contato com o modernismo, aderiu à sua utilização. A volta à forma fixa se daria nas obras da chamada "fase final" da poesia limiana - como a denomina Fábio de Souza Andrade (1997) -, compreendendo o Livro de sonetos e Invenção de Orfeu. Especificamente nesta, a forma fixa - cultivada sob vários moldes - se alia à confecção de um poema épico, num momento em que tal gênero gozava de pouco prestígio, estando praticamente consolidada a ideia de o épico ser um gênero inadequado para a expressão de problemas do homem moderno. ${ }^{3}$ Nesse contexto, é significativo que a inserção de um poema de verso livre em Invenção de Orfeu tematize justamente o

3 No Brasil a busca pela literatura de expressão nacional, empreendida de maneira pontual desde o romantismo, ofereceu um importante capítulo sobre a discussão do gênero épico. Refiro-me à polêmica iniciada por José de Alencar (1960) a respeito d'A confederação dos tamoios, poema épico de Gonçalves de Magalhães patrocinado por D. Pedro II como parte dos esforços para a consolidação do desejo de diferenciação em relação a Portugal, no bojo do sentimento recente de independência. Sob o pseudônimo de Ig, Alencar publicou nos jornais da época críticas à obra, defendendo que a epopeia não era um gênero propício para a efetivação do projeto de consolidação da literatura nacional; a ela, preferiu o romance, embora depois tenha recuado do radicalismo de sua posição e tentado escrever uma epopeia 
fracasso do poder encantatório da lira de Orfeu, dispensando a utilização de recursos melódicos - talvez uma advertência quanto ao desgaste do próprio versolibrismo modernista ou ainda consciência de que a tradição métrica não tem mais efeito encantatório e redentor.

A imagem mitológica de Orfeu dedilhando sua lira é base para a desconstrução que se opera no poema: sua enorme e suave destra é inexistente, inibida, vaga e humana, encontrando o vazio quando se abate sobre o peito. Seus dedos são "apenas cinco sinos sem seu íris”, indicando, por metonímia, o comprometimento do canto no instrumento defeituoso, a que falta justamente o objeto que produz som. Até o oitavo verso, Orfeu constata a imposição de um sofrimento. $\mathrm{O}$ gesto da mão abatendo-se no peito sinaliza sua desolação; se antes foi "delação das coisas", anunciando a composição de um microcosmo a partir do canto, através do qual as coisas passam a existir, agora está inibida porque ecos a destroem. Aquilo que Orfeu produziu pelo canto retorna contra ele como "sublevação".

Do nono ao décimo sétimo verso, percebe-se que os ecos que martelam a mão de Orfeu, desterrada ("êxul”) do próprio ofício, advêm dos relinchos de éguas que agora se anulam nos silêncios. A imagem das "éguas da fecundação final, [...] planturosas e cheias de pistilos", mobiliza a fusão das categorias animal e vegetal, masculino e feminino, para compor a metáfora da fecundidade e do erotismo estéreis, construída no poema. Representativas da feminilidade, as éguas possuem pistilos, que compõem o gineceu, órgão feminino reprodutor das plantas; porém, os pistilos têm forma fálica, reforçada por meio da aparência conferida pela imagem poética: viscosos como lesmas e vermelhos. Se, no quinto verso, os ecos martelavam a mão de Orfeu, no décimo quarto são os relinchos das éguas que o fazem; portanto, ecos e relinchos se sobrepõem. Nos versos décimo quarto e décimo quinto, os ecos são atribuídos ao próprio Orfeu. A voz poética reconhece a degeneração do poder encantatório, marcando a diferença entre sua imagem passada e a presente: "deus sonoro e terrível, hoje vago, vago / tão vago como sua vaga destra”. A humanização de Orfeu relaciona-se à fraqueza adquirida: ele é o responsável pela perda da própria habilidade musical, pela indeterminação de seu canto, na medida em que perde sua condição divina e torna-se humano, fraco, como Adão após a Queda. 
Do décimo oitavo ao vigésimo primeiro verso, enfatiza-se a humanização de Orfeu e a responsabilização pelo próprio fracasso: seus dedos são "apenas dedos reais humanos" e sua destra não é mais habilidosa "com os androceus dos dedos musicais". A referência ao órgão reprodutor masculino das plantas completa a metáfora da falência da fecundidade: as éguas com seus pistilos, cujos relinchos se sobrepõem aos ecos de um Orfeu agonizante e humanizado, consumariam a "fecundação final"? No reino vegetal, é indispensável a presença de um agente polinizador para levar o pólen do androceu ao gineceu, a fim de que a fecundação ocorra e gere uma nova planta. No poema, esse movimento parece estar comprometido porque Orfeu, antes um deus sonoro, perde a dádiva do canto e seus dedos/androceus estão enfraquecidos. Portanto, nada mais nasce da lira de Orfeu.

Os sete versos finais dizem respeito à figura do poeta, deão de cerimônias de Orfeu que lhe inventa os gestos. No começo do poema, ao abater sobre o peito sua destra, antes musical, Orfeu depara "funda ausência”, inaptidão para a música; agora o poeta conduz sua mão a outra profundidade, "funda submersão [...] ao seio dos infernos", terreno em que, no contexto do Canto II, habitam os pecadores mortos que povoavam a ilha. Orfeu "delatava”, anunciava as coisas; agora "delata”, anuncia o próprio poeta. Por sua vez, o poeta desvela a "aparência" de Orfeu em função de uma imagem mais "real", mais humana, mais coerente com o universo que o rodeia e, por isso, decaída, imersa no subsolo infernal da ilha. Eis uma leitura possível para a dupla "invenção" 4 a que o título da obra remete: o poeta inventa Orfeu na mesma medida em que é inventado por ele, ambos humanizados, ambos interditados ao poder fundante da palavra poética, reservado a um universo sagrado que se mostra refratário aos homens. Se a lógica pós-edênica coloca a redenção dos pecados no além-mundo cristão, Orfeu e o poeta, sem conseguirem se alçar à temporalidade do sagrado, permanecem excluídos do domínio da poesia.

Maurice Blanchot chamou a atenção para o gesto imperativo de Orfeu, que sacrifica a si próprio e a sua arte na busca por flagrar uma

$4 \mathrm{Na}$ nomenclatura gramatical, a diferença aí estabelecida se dá entre o "adjunto adnominal" e o "complemento nominal". O adjunto adnominal acompanha um nome, especificando-o, podendo indicar o agente, no caso de substantivos transitivos que nomeiam uma ação verbal; já o complemento nominal é um termo que completa o sentido de um nome transitivo, podendo, para o mesmo caso, indicar o termo paciente. Em "invenção de Orfeu", o termo "de Orfeu" é adjunto adnominal quando se entende que "Orfeu inventa algo" e complemento nominal se "alguém inventa Orfeu”. 
Eurídice obscura que lhe era interdita. Para o filósofo francês, a obra de arte pertenceria a um espaço regido por leis próprias, em que os objetos são subtraídos de sua lógica cotidiana e colocados sob a luz da inutilidade, tão estranha à nossa percepção, já que nos orientamos segundo a lógica diurna e utilitária da "vida ativa" (BLANCHOT, 2011, p. 41). Para tanto, é preciso que o artista se submeta à "exigência da obra" (p. 42) - e não o contrário, isto é, que a obra se submeta à vontade do artista de subtrair os objetos de sua utilidade -, distanciando-se do tempo do mundo e do trabalho para finalmente poder contemplar esse lugar em que os objetos perdem a utilidade. $\mathrm{O}$ produto dessa atividade é, igualmente, avesso à lógica diurna: "escrever é abordar aquele ponto em que nada se revela, em que, no seio da dissimulação, falar ainda não é mais do que a sombra da fala, [...] murmúrio do incessante e do interminável a que é preciso impor silêncio, se se quiser, enfim, que se faça ouvir" (p. 43, grifo do autor). O trabalho do artista, portanto, só se realiza na sua impossibilidade, daí a tensão que, para Blanchot, o caracteriza.

Assim, nomomentoem queOrfeu/artista procuraapreender Eurídice/ obra em sua obscuridade, naquilo que é a impossibilidade por princípio, isto é, olhar o que não pode ser olhado, é a decisão audaciosa do artista que resulta em sua própria aniquilação. Orfeu "nesse olhar, está ausente, não está menos morto do que ela [Eurídice], não a morte dessa tranquila morte do mundo que é repouso, silêncio e fim, mas dessa outra morte queé sem fim, prova da ausência de fim" (BLANCHOT, 2011, p. 188, grifo nosso): quando decide abdicar da obra a fim de apreender o inapreensível, Orfeu condena-se a permanecer em sua ausência. A lembrança dessa Eurídice obscura que ele quer fazer permanecer é precária, não se concretiza, não se faz presença; ao passo que sua ausência, consequente da decisão de olhar o que não pode ser olhado, torna-se presença desde então: nunca mais Orfeu sairá desse espaço que é lugar nenhum, nunca mais será reintegrado à "vida ativa”.

Em Invenção de Orfeu, a consciência do poeta de que a tarefa a desempenhar pela poesia é uma atitude sacrificial, tal qual a de Orfeu quando descumpre a condição imposta pelos deuses, confere tensão ao movimento contraditório que estrutura o poema. Se, de um lado, reconhece a pouca eficácia da palavra poética para a fundação de uma nova cosmogonia, de outro sabe que não pode abandonar sua tarefa, como se estivesse submetido à "tormenta da inspiração" blanchotiana. No poema XI do Canto VII, "Audição de Orfeu”, assim como se observa em 
outras passagens, o poeta apresenta a eleição para a poesia como fonte de tormenta:

Interroga-me o Rei. E eu em voz gasta:

Minha mão artesã pertence à lei, e com ela registrei nas colunatas:

Ó intangível céu, enfim cansei.

Fiquei então ao alto, nesses frisos.

(Eis um pastor oculto me rondando).

Meu ânimo querido dos estilos

olhava do alto o chão e o pastor, quando

a vida era contínua; e as sombras n'água

tremiam o reflexo das ruínas.

Decidi-me de cima desabar-me.

E desabando-me eis que ainda escutei

aquela voz tão grave e tão divina:

fui teu céu; e teu chão sempre serei

(LIMA, 1997, p. 692).

Esse soneto decassílabo apresenta o fazer poético a partir da referência à busca do sagrado e pela interlocução estabelecida com uma voz divina. A cena apresentada assinala a distância entre o poeta e o universo do sagrado. Na primeira estrofe, o poeta afirma estar a serviço da revelação divina: é um artesão submetido à lei, ou seja, a algo que lhe é imposto; está sendo interrogado, porque deve prestar contas de sua atividade. Responde com um desabafo, dizendo-se cansado de buscar o inatingível - o que parece subverter a lei, embora tal subversão seja produzida em consonância com seus pressupostos.

Numa leitura possível do Velho Testamento, o mistério de Deus seria inatingível porque o homem não respeitou sua lei desde o princípio dos tempos. A vontade de igualar-se a Deus, consequente do orgulho, será sempre punida (CHOURAQUI, 1995, p. 117): primeiramente, com a expulsão do paraíso edênico e, depois, com a desagregação dos povos no episódio da Torre de Babel.5 O drama da Queda traz consequências

5 Nesse episódio, os descendentes de Noé decidem erguer uma torre tão alta que alcançasse o céu, a fim de ficarem conhecidos e não se dispersarem pela terra. Porém, o projeto não se concretiza: "E Iahweh disse: 'Eis que todos constituem um só povo e falam uma só língua. Isso é o começo de suas iniciativas! Agora, nenhum desígnio será irrealizável para eles”" $(\mathrm{Gn}$ 11, 6). Deus o arruína temendo que esses homens, no futuro, pudessem construir tudo o que desejassem. Como falassem apenas uma língua, Deus os confunde incutindo em cada um uma língua diferente, e assim a construção não pôde ser continuada.

Remate de Males, Campinas-SP, v. 37, n. 1, pp. 217-239, jan./jun. 2017 
drásticas que obrigam o homem a reorganizar a vida sem a presença de Deus; o segundo episódio traz a perda da unidade da linguagem. O próprio Deus, que criara a mundo através da palavra, reconhece na narrativa bíblica que a linguagem permite aos homens, unidos, realizarem tudo o que desejam, inclusive possibilitaria o retornoà morada celeste. O episódio da Torre de Babel, que põe em relevo o acesso ao mistério de Deus como um problema de linguagem, cujo impedimento é consequente das ações humanas, é também referido em Invenção de Orfeu: "Inlucidez humana. Tatear nosso. / Muitos nomes perdemos. Restam línguas / mutiladas, sem asas, tartamudas. // Pensamentos travosos, verbos lentos, / e a dureza do exílio relembrada!" (LIMA, 1997, p. 794). Nesses versos, o poeta evoca o episódio pela mutilação da linguagem, que traz consequências para o fazer poético: a obsessão humana em alcançar a divindade retirou da linguagem a capacidade de alçar voos, de fundar novas cosmogonias; perderam-se os nomes capazes de designar a comunhão com o sagrado, buscada no poema, que está marcado pelo drama da Queda.

É nesse contexto de negação do poder fundante da palavra poética que o poema XI do Canto VII se refere à distância entre o homem e a dimensão do sagrado. O poeta, como eleito para a tarefa da poesia, põese em tensão: se não pode alcançar o "intangível céu", também não lhe é permitido interromper o caminho em direção a ele. A partir da segunda estrofe, o poeta, que observa o mundo do alto, embora o céu lhe seja inalcançável, decide "desabar-se", tentado, talvez, pela figura de Lúcifer, sugerida pelo oculto pastor que o vigia, anjo banido dos céus, tal qual ele deseja se tornar, ${ }^{6}$ pois está cansado da busca sem sucesso. A resposta da voz divina marca a impossibilidade de o poeta se libertar da tarefa a que está submetido: "fui teu céu; e teu chão sempre serei". Caído do céu, o poeta encontra um chão que também pertence à lei de Deus.

O canto em que esse poema se insere, Canto VII - "Audição de Orfeu" -, ao contrário do que sugere o título, tem o silêncio como imagem recorrente; a lira de Orfeu não é mais encantatória, já não apazigua as guerras, não enternece o coração de seus opositores. Embora o poema III desse Canto aponte para a afirmação da palavra poética, ela é reconhecida como desejo, não como efetividade, como vimos. O que o poeta constata

6 A identificação entre o poeta e Lúcifer aparece em outras passagens de Invenção de Orfeu, tal como nos seguintes versos: "arcanjo renegado que ainda sou" (LIMA, 1997, p. 556).

Remate de Males, Campinas-SP, v. 37, n. 1, pp. 217-239, jan./jun. 2017 
diante da história da humanidade pode ser lido nesta pergunta: "Ó dizeme, canção, que verbo ardente / virá desses caminhos taciturnos?" (LIMA, 1997, p. 681). O poeta, na sua busca por reencantar o mundo que não lhe oferece matéria poética, sabe que não pode fazê-lo, pois reconhece a ineficácia de sua mensagem. O poeta se apresenta como um estrangeiro, um exilado, incendiado pela presença de Orfeu, inflamado pela loucura que sua condição ambígua lhe confere. Sua voz é a de um excluído, a quem não se deve dar ouvidos, obrigado a amargar a memória da Queda. As palavras que pronuncia são tão incompreensíveis e, portanto, tão inúteis quanto o zumbir das abelhas: "Ali está o poeta: tem nos brandos lábios / a abelha vã, a abelha quase louca, / a abelha zumbidora [...]" (p. 683). No poema VI desse canto, ora quer demitir-se de seu ofício e conclamar os demais poetas a silenciarem; ora pede a Deus que o livre dos solilóquios e rende-se aos seus desígnios: "Mendigo de pedir retorno a ser, ó Deus! / E peço-te Lenora, e peço-te meu canto!" (p. 689). A tensão entre dar continuidade a seu "ofício parvo" (p. 679) e renunciar a ele, que é a tônica desse canto, é sintetizada ao final do poema VI, em que o poeta se vê entre deus e o diabo: "Ó esta viagem pela encruzilhada ardente / tão cheia de dragões de cada lado olhando-me: / um me escarnece enquanto o outro sendo tridente / não me desfaz da voz asas desse amanhã!" (LIMA, 1997, p. 69o). Se o primeiro zomba do poeta e o incita a se rebelar, o outro lhe oferece a esperança de que consiga cumprir sua tarefa. $O$ tridente, item que geralmente remete à figura do diabo, parece nesses versos associado à Santíssima Trindade.

Blanchot (2011, p. 32) acredita que a linguagem literária se distingue tanto da linguagem cotidiana quanto da linguagem do pensamento: ela "provém do silêncio e ao silêncio retorna", ao qual toda a determinação escapa. É, portanto, uma linguagem que se anula, que se faz presença pela ausência; por isso, ela nada revela. Mas essa impossibilidade seria uma impossibilidade afirmativa, "não porque seja o simples reverso das formas variadas de possibilidade, mas porque designa uma região onde a impossibilidade já não é privação, mas afirmação" (p. 242). Essa impossibilidade afirmativa, no entanto, não se integra à vida cotidiana. Por isso, o artista viveria atormentado por ter de lidar com a condição de inutilidade da tarefa a que se dedica. Blanchot entende que os diários pessoais, em que o escritor tenta se recuperar do autossacrifício que se impõe ao escrever a obra, funcionam como uma espécie de "memorial", de 
aproximação do escritor com a vida cotidiana, "quando é um ser vivente e verdadeiro, não agonizante e sem verdade” (p. 2o).

No caso de Invenção de Orfeu, é na própria obra que a tensão se dá: sendo seu personagem o poeta que busca fundar a ilha por meio da palavra, é nesse mesmo espaço que ele expressa o sacrifício a que está submetido para a execução da obra. Se, por um lado, ele busca na palavra poética a força encantatória de Orfeu, tanto mais necessária quanto mais o mundo se mostra refratário a ela, por outro, percebe que é a própria palavra poética que se mostra refratária a ele:

Um momento há na vida, de hora nula, em que o poema vê tudo, viu, verá;

e a si mesmo, na cera em que se anula, sob o fogo dos céus, consumir-se-á.

Há nas fomes dos tempos, uma gula, umas vicissitudes, fados, ah!

Há tempos em que o canto se modula sob o sibilo de cassandra má.

Vejo morrer, ó céus, em dura lei, meus membros, minhas vísceras, meus ossos sob as rosas de lava que inventei.

Antes que os lábios, amanhã, ó poema, hirtos se calem, vossos, serão vossos, esses cânticos de renunciação

(LIMA, 1997, p. 675).

Esse poema encerra o Canto VI - "Canto da desaparição" -, pontuado de imagens da falência da poesia, de naufrágios, em que o presente da enunciação se refere a um universo degenerado. Uma das figurativizações da desaparição dos signos poéticos é a Paixão de Cristo, referida em dois poemas (V e VI), em que se ressaltam seus sofrimentos e a indiferença à sua morte; remete, portanto, à desaparição de um símbolo que deveria servir de alento à humanidade, ao qual esse canto não parece se render. Seu tom, ao contrário, é apocalíptico: "Aqui é o fim do mundo" (LIMA, 1997, p. 660); “Tudo é luto e pavor" (p. 670); "A ilha é um pranto imenso" (p. 671) onde o poder fundante da palavra poética cede lugar à constatação de sua ineficácia. 
O soneto de tradicionais versos decassílabos segue nos quartetos um esquema rímico ${ }^{7}$ em que o primeiro verso rima com o terceiro, o quinto e o sétimo; o segundo, com o quarto, o sexto e o oitavo. Em se tratando dos tercetos, somente o primeiro o faz, sendo o último composto por dois versos (o décimo segundo e o décimo quarto) que não rimam entre si ou mesmo com qualquer outro verso do soneto. O último verso, apesar de não rimar com os demais, estabelece com o penúltimo uma rima interna que, posta em relevo, alteraria o ritmo do decassílabo: "hirtos se calem, vossos, serão / vossos esses cânticos de renunciação”. O último verso, considerado tradicionalmente um elemento de grande valor para o soneto, trazendo a "essência do pensamento geral da composição" (BILAC, 1905, p. 164), cuja rima é sua chave de ouro, é justamente o ponto em que o esquema se rompe, detalhe que, dentro da forma fixa, como estruturação da linguagem poética, reforça o tema da desintegração do canto.

Numa outra perspectiva, a opção pela ausência da rima no último verso pode ser índice da tensão na linguagem poética entre o som e o sentido, como a vê Agamben (2002). Se a possibilidade de enjambement caracteriza a linguagem poética, o último verso de um poema, ao qual o recurso não pode ser aplicado, indica uma crise do verso, "como se o poema, enquanto estrutura formal, não pudesse, não devesse findar, como se a possibilidade do fim lhe fosse radicalmente subtraída, já que implicaria esse impossível poético que é a coincidência exata de som e sentido" (p. 146). A desvinculação do verso final com os demais indicaria que "o poema procura uma saída suspendendo por assim dizer, o próprio fim, numa declaração de estado de emergência poética” (p. 146), que marca sua fragilidade por denotar a impossibilidade de que a linguagem poética se prolongue no tempo. Ao suspender o final do poema com a aliança, proposta ao leitor, de recomeçá-lo, Invenção de Orfeu amplifica o recurso do enjambement, no sentido empregado por Agamben, criando uma circularidade desesperadora (afinal, tratam-se de cerca de trezentas páginas), radicalizando a percepção de uma crise da linguagem poética.

O poema tem como tema a própria dissolução numa "hora nula", de revelação visionária que engloba presente, passado e futuro, quando o poema "tudo vê". Sondar a revelação é lidar com o imponderável: o

7 Olavo Bilac (1905, p. 168), em seu Tratado de versificação, afirma que, embora nunca tenha havido regras fixas para a colocação das rimas no soneto, a mais praticada, em relação aos dois quartetos, é aquela em que o primeiro verso rima com o quarto, o quinto e o oitavo; e o segundo, com o terceiro, o sexto e o sétimo. A posição que observaremos a seguir é listada por Bilac como uma variante.

Remate de Males, Campinas-SP, v. 37, n. 1, pp. 217-239, jan./jun. 2017 
momento em que ela se dá equivale ao momento em que ela se perde, tal como quando Orfeu volta o olhar para Eurídice e não pode retê-la em sua obscuridade, ou quando se busca apreender o instante da morte. Por meio da revelação da linguagem poética, o mundo desaparece, já que ela nada pode revelar, e a linguagem deixa de ser referencial, representativa das coisas, para ser presença da ausência (BLANCHOT, 2011, p. 39): a única coisa que a revelação diz é que, ao se dar pelo poema, ela desaparece e o consome. Esse momento é marcado por vicissitudes, contidas nas "fomes dos tempos”, insaciáveis; é um tempo de crise, daí o canto se modular "sob o sibilo de cassandra má”. A personagem mitológica aí referida permite ler a imagem do poeta como um visionário cujas profecias são descreditadas. ${ }^{8}$ Se o tempo em que o poeta se encontra é regido por Cassandra, sua habilidade com a palavra poética torna-se inútil e vai levá-lo à anulação de si, pela "dura lei" que mutila seus membros. Sua invenção poética são "rosas de lava”, poema que se consome à medida que se faz. Resta-lhe, ao final, registrar sua renúncia ao canto, impor-lhe seu silêncio, pois esse é o único poder que, por hora, a palavra refratária da revelação lhe concede.

Identificado a um "novo Orfeu" (LIMA, 1997, p. 589), o poeta oferece de si a imagem de alguém que sofre a tensão advinda da impossibilidade de realizar a tarefa para a qual se consagra. Diante da falência da tentativa de fundar um mundo por meio da palavra poética, já que seu sucesso é precário, o poeta reconhece a impotência da linguagem como inerente à condição humana: "Metal humano em chama purgatório, / fumando claridades de um minuto, / mas sofrendo na carne, mas sofrendo / o instrumento da voz que vem rachado" (p. 729, grifo nosso). Os versos apontam a condenação humana, a precariedade do afastamento dessa condição na fruição de "claridades" momentâneas e o sofrimento imposto pelo impedimento da linguagem. Nesse sentido, contrariamente à hipótese blanchotiana de que a linguagem literária se distingue das linguagens do cotidiano e do pensamento, o poeta afirma a proximidade entre esses diversos registros. Toda linguagem é impotente - dimensão que o leitor experimenta è qual o poema confere visibilidade.

A imagem de Orfeu permite ao poeta afirmar o poder fundante da palavra ante um mundo refratário à poesia, desejando para si a habilidade

8 Cassandra, quando criança, teve os ouvidos beijados por serpentes, e isso a tornou sensível à voz dos deuses; posteriormente, tendo se recusado a dormir com Apolo, que por ela se apaixonara, a jovem é amaldiçoada pelo deus, que faz com que ninguém mais dê atenção às suas profecias.

Remate de Males, Campinas-SP, v. 37, n. 1, pp. 217-239, jan./jun. 2017 
órfica de encantar o mundo por meio da suspensão do caos. Ao mesmo tempo, um Orfeu fraco, cujo canto silencia, revela ao poeta que não só o mundo é refratário à poesia, mas que a própria obra poética é refratária a seu criador. A permanência do mistério se dá como exclusão do poeta de seus domínios. A afirmação do poder fundante da palavra poética se transforma em negação afirmativa, que constata a impropriedade da tarefa a que o poeta se consagra.

Invenção de Orfeu é uma obra que coloca a realização poética sempre no plano de uma vontade não efetivada. Escrever o poema é um trabalho que o poeta toma como fracasso irremediável, tentativa repetida à exaustão e que terminará inconclusa ou falida: "emudeço / com uma hesitação que vem do início; / só tenho algumas vozes mas tão trôpegas / que mais parecem fontes embriagadas" (LIMA, 1997, p. 537). O poeta expressa o desejo de silenciar desde o momento em que se pôs a escrever o poema; este permanecerá como "hesitação", cujo resultado é uma conjunção de vozes embriagadas. Assim, o canto muitas vezes é formulado a partir de sua negação, como nesta estrofe do Canto VIII, "Biografia":

\footnotetext{
Se alguma ave cantou, cantou em nunca, sumariamente nula nesse flórido cômodo desprazido, talvez ermo, num metal quilométrico sem aros para aguentar o morto que me levam sepulto entre meus pés e teus soluços (LIMA, 1997, p. 740).
}

A ave, como figura do poeta, é apresentada a partir de sua anulação, característica que o canto também assimila. O lugar em que a ave nula pronuncia o canto é delineado com adjetivos contraditórios: flórido e desprazido, próspero mas que causa desgosto, o que talvez se possa relacionar com a situação contraditória do poeta, entre afirmar e negar o poder fundante da palavra. O poeta anuncia seu funeral segundo uma construção sintática que parece revelar ao mesmo tempo distanciamento e aproximação da voz enunciativa à situação descrita: "o morto que me levam sepulto entre meus pés”. O lugar em que a ave nula canta é também o lugar em que seu corpo será posto, "metal quilométrico sem aros", imagem que sugere, pela extensão e inteireza do metal, o peso de seu corpo, figura 
da gravidade de seu sofrimento. Assim, o lugar em que a ave nula canta pode ser lido como o próprio poema: lugar contraditório que termina por indicar a autoanulação do poeta.

O poema propõe uma equação insolúvel: afinal do que o sacrifício do poeta nos preserva? Se o sacrifício do poeta resulta em poema, este não nos oferece sequer a suspensão do caos mundano proporcionada pela lira de Orfeu, pois se apresenta como organismo adoecido por um mundo degenerado. Essa tensão indica a reciprocidade entre as instâncias: a efetivação no plano poético da fundação de mundo pela palavra incidiria no mundo degenerado. Em outras palavras: a "cura" da linguagem poética também seria a "cura" do mundo. A unidade que se busca diz respeito justamente a esse projeto impossível, de fazer com que o verbo poético se faça carne na história humana.

\section{REFERÊNCIAS BIBLIOGRÁFICAS}

AGAMBEN, Giorgio. O fim do poema. Trad. Sérgio Alcides. Cacto, São Paulo, no 1, Alpharrabio, 2002, pp. 142-149.

ALENCAR, José de. Cartas sobre A confederação dos tamoios. In: . Obra completa. Vol. 4. Rio de Janeiro: José Aguilar, 196o, pp. 865-922.

ANDRADE, Fabio de Souza. O engenheiro noturno: a lírica final de Jorge de Lima. São Paulo: Editora da Universidade de São Paulo, 1997a (Críticas Poéticas; 6).

BÍBLIA DE Jerusalém. São Paulo: Paulus, 2006.

BILAC, Olavo. Tratado de versificação. Rio de Janeiro: Livraria Francisco Alves, 1905.

BLANCHOT, Maurice. O espaço literário. Trad. Álvaro Cabral. Rio de Janeiro: Rocco, 2011.

CANABRAVA, Euríalo. Jorge de Lima e a expressão poética. In: LIMA, J. de. Jorge de Lima: poesia completa. Org. Alexei Bueno. Rio de Janeiro: Nova Aguilar, 1997, pp. 112-121.

CHOURAQUI, André. No princípio. Trad. Carlito Azevedo. Rio de Janeiro: Imago Ed., 1995.

ELIADE, Mircéia. História das crenças e ideias religiosas, volume I: da Idade da Pedra aos mistérios de Elêusis. Trad. Roberto Cortes de Lacerda. Rio de Janeiro: Zahar, 2010.

ELIADE, Mircéia. História das crenças e ideias religiosas, volume II: de Gautama Buda ao triunfo do cristianismo. Trad. Roberto Cortes de Lacerda. Rio de Janeiro: Zahar, 2011.

LIMA, Jorge de. Invenção de Orfeu (Poemas). In: Rio de Janeiro: Nova Aguilar, 1997, pp. 505-802. . Jorge de Lima: poesia completa. 
MÉNARD, René. Mitologia greco-romana. Vol. 2. Trad. Aldo Della Nina. São Paulo: Opus, 1991.

MERQUIOR, José Guilherme. Razão do poema: ensaios de crítica e de estética. Rio de Janeiro: Topbooks, 1996.

SPTIZER, Leo. La enumeración caótica en la poesía moderna. In: . Linguüistica e historia literaria. Trad. Raimundo Lida. Madrid: Editorial Gredos, 1968, pp. 247-291.

STAIGER, Emil. Conceitos fundamentais da poética. Trad. Celeste Aída Galeão. Rio de Janeiro: Tempo Brasileiro, 1969.

TELLES, Gilberto Mendonça. Camões e a poesia brasileira. Rio de Janeiro: Livros Técnicos e Científicos, 1979 .

VASCONCELOS DA SILVA, Anazildo \& RAMALHO, Cristina. História da epopeia brasileira: teoria, crítica e percurso. Rio de Janeiro: Garamond, 2007. 